Diabetologia 10, 69-75 (1974)

(C) by Springer-Verlag 1974

\title{
Interrelationship between Glucose and Acetoacetate Metabolism in Human Adipose Tissue
}

\author{
A.H. Kissebah, B. R. Tulloch and T.R. Fraser \\ Endocrine Unit, Department of Medicine, Royal Postgraduate Medical School, Ducane Road, London W 12 OHS
}

Received: June 1, 1973, and in revised form: October 15, 1973

Summary. We have examined the utilisation of glucose and ketone bodies in normal adipose tissue in response to insulin and some drugs used in diabetic therapy. Under basal conditions ${ }^{14} \mathrm{C}$ from acetoacetate was incorporated into long chain fatty acids, while ${ }^{14} \mathrm{C}$ from glucose was found principally in the glyceride glycerol fraction of tissue lipids. Fatty acid synthesis from acetoacetate was stimulated ten-fold by glucose addition up to $20 \mathrm{mM}$ and conversely, acetoacetate enhanced the incorporation of glucose ${ }^{14} \mathrm{C}$ into lipids. The stimulatory effect of glucose was independent of its transport, since it is not reproduced by 2 -deoxy-glucose. Insulin further stimulated fatty acid synthesis from acetoacetate, an effect abolished in the absence of glucose. Phenethyl-biguanide (Phenfor- min) increased tissue glucose uptake, although it decreased glucose ${ }^{14} \mathrm{C}$ and acetoacetate ${ }^{14} \mathrm{C}$ incorporation into triglyceride. Free fatty acids (FFA) and very low density lipoproteins (VLDL) addition at concentrations observed in diabetic ketosis resulted in inhibition of acetoacetate utilisation. We conclude that ketone bodies do not block glucose utilisation in normal human adipose tissue in vitro. The apparent reduction in ketone body metabolism during diabetic ketosis may be related to the high FFA and VLDL levels observed.

Key words: Human adipose tissue, glucose, ketone bodies, long-chain fatty acids, triglyceride, phenethylbiguanide.
The mechanism of insulin resistance during diabetic ketosis is not well understood. Some reports have suggested an impairment of glucose metabolism in muscle exposed to high concentrations of aceto-acetate and beta-hydroxybutyric acid $[1,2]$. Randle and his colleagues [3, 4], working with perfused rat heart, suggested a reciprocal relationship between ketone body oxidation and glucose metabolism. From their observations they derived the hypothesis that during ketone body oxidation the intracellular level of acetyl $\mathrm{CoA}$ is raised at the expense of free CoA, resulting in inhibition of glucose utilisation. These investigations suggest that the rising concentration of plasma ketone bodies during diabetic ketosis might be responsible, at least in part, for the insulin resistance observed. Acetoacetate and beta-hydroxybutyrate serve as readily metabolisable substrates in rat adipose tissue [5]. Furthermore, rat adipose tissue could effectively synthesise fatty acid from ketone bodies in vitro $[6,7]$.

It seemed reasonable, therefore, to test whether this antagonism could be detected in man. In the present investigation we have explored the interrelationship between ketone body metabolism and glucose utilisation in normal human adipose tissue.

\section{Materials and Methods}

\section{Adipose Tissue}

Subcutaneous human adipose tissue was obtained during routine surgery from 16 patients with normal fasting blood sugar. Patients with jaundice, uraemia or other metabolic disease were excluded. Pre-medication was with Nembutal and general anaesthesia was induced by Pentothal and maintained with either Cyclopropane and oxygen or Halothane and nitrous oxide, with oxygen. The adipose tissue was removed early in the operation and transferred to the laboratory in $0.9 \%$ saline. Rat adipose tissue was obtained from the epididymal fat pads of $150-200 \mathrm{~g}$ male Wistar rats after an overnight fast.

\section{Incubation Conditions}

Adipose tissue pieces $(50-100 \mathrm{mg})$ were incubated for $2-6 \mathrm{~h}$ in $1 \mathrm{ml}$ of Kreb's bicarbonate buffer, $\mathrm{pH} .7 .4$, containing $2 \%$ bovine serum albumin (Armour, recrystallised). Incubations were performed in polystyrene tubes, stoppered with rubber caps supporting a hanging well $11 / 2$ by $1 \mathrm{~cm}$. Incubation was carried out in an atmosphere of $95 \% \mathrm{O}_{2}$ and $5 \% \mathrm{CO}_{2}$ at $37^{\circ} \mathrm{C}$ in a metabolic shaker. The substrate concentrations and specific activity of the labelled compounds are shown in each table. After incubation, $0.5 \mathrm{ml}$ of $1 \mathrm{M}$ hyamine was introduced into the centre well through the rubber cap. $0.4 \mathrm{ml}$ of $1 \mathrm{~N}$ sulphuric acid were then introduced via the side arm into the main compartment of the incubation tubes. This stopped the reaction instantly and ensured complete liberation of the $\mathrm{CO}_{2}$. The incubation tubes were returned to the metabolic shaker for a further $1 \mathrm{~h}$ to ensure complete transport of the $\mathrm{CO}_{2}$ to hyamine.

\section{Assay of Compounds}

The $\mathrm{CO}_{2}$ from glucose or aceto-acetate metabolism was determined by transferring the central well containing the hyamine to a counting vial with $10 \mathrm{ml}$ of scintillation fluid (Toluene PPO + PPOP). Using known concentrations of labelled sodium bicarbonate, the efficiency of $\mathrm{CO}_{2}$ recovery was determined and the counts corrected accordingly. After incubation, adipose tissue pieces were removed, rinsed several times in cold saline and extracted in $15 \mathrm{ml}$ of chloroform-methanol 
[8]. The washed extract was dried under nitrogen and saponified in alcoholic KOH at $60^{\circ} \mathrm{C}$ for $1 \mathrm{~h}$. Completeness of saponification under these conditions was checked by thin layer chromatography as below. After saponification, the glyceride glycerol and fatty acids were isolated and determined according to the method of Denton and Randle [9]. Separation of the total lipids into single lipid classes was performed on aliquots of unsaponified extract using thin layer chromatography in a solvent system of diethyl ether, heptane and acetic acid $(80: 20: 2)$. The lipid fractions were identified by iodine vapour, decolourised and counted. The radioactive glycogen was isolated from the delipidated tissue using the method of Stetten et al. [10]. $20 \mathrm{mg}$ of nonradioactive glycogen were added to each tube to serve as a recovery mixture. After isolation the purified glycogen was dissolved in $0.5 \mathrm{ml}$ of water and counted in $10 \mathrm{ml}$ of toluene PPO/PPOP containing $30 \%$ triton. Corrections for quenching were performed using internal standards. Glucose in the medium was measured using the glucose oxidase method of Cramp [11].

\section{Materials}

Uniformly labelled glucose ${ }^{14} \mathrm{C}$ and ethyl acetoacetate ${ }^{3-14} \mathrm{C}$ were obtained from Amersham Radiochemicals, England. Acetoacetate and $3-^{14} \mathrm{C}$ acetoacetate were freshly prepared, daily, by the method of Krebs and Egglestone [5]. Reagents for glucose estimation were purchased from Boehringer Corporation, England. Phenethyl biguanide (Phenformin, sodium salt) was generously supplied by Winthrop Pharmaceutical Company. Kieselgel chromatography plates $(20 \mathrm{~cm} \times 20 \mathrm{~cm})$ were obtained from Merck $A / G$, Darmstadt, West Germany. Insulin (6-fold recrystallised) was obtained from Boots Pure Drug Co. and chlorpropamide from Hoechst Pharmaceuticals.

\section{Results}

\section{a) Glucose and Acetoacetate Metabolism in Human and Rat Adipose Tissue}

The conversion rate of ${ }^{14} \mathrm{C}$ glucose into glyceride glycerol, glyceride fatty acids, glycogen and $\mathrm{CO}_{2}$ by human and rat adipose tissue is shown in Fig. 1. In contrast to rat adipose tissue, the major fraction of glucose metabolised by the human tissue was recovered in the glyceride glycerol. Less than $4 \%$ of the radioactivity from glucose was incorporated into fatty acids. ${ }^{14} \mathrm{C}-3$ acetoacetate, on the other hand, was mainly metabolised into glyceride fatty acids and $\mathrm{CO}_{2}$ by human and rat adipose tissue.

\section{b) The Effect of Glucose on ${ }^{14} \mathrm{C}$ Acetoacetate Metabolism}

In the presence of glucose $20 \mathrm{mM}$ the incorporation of acetoacetate into total lipids by human adipose tissue shreds was linear up to $6 \mathrm{~h}$ (Fig. $2 \mathrm{a}$ ). When the glucose concentration in the medium was raised from 5 to $40 \mathrm{mM}$, incorporation rate of acetoacetate into total

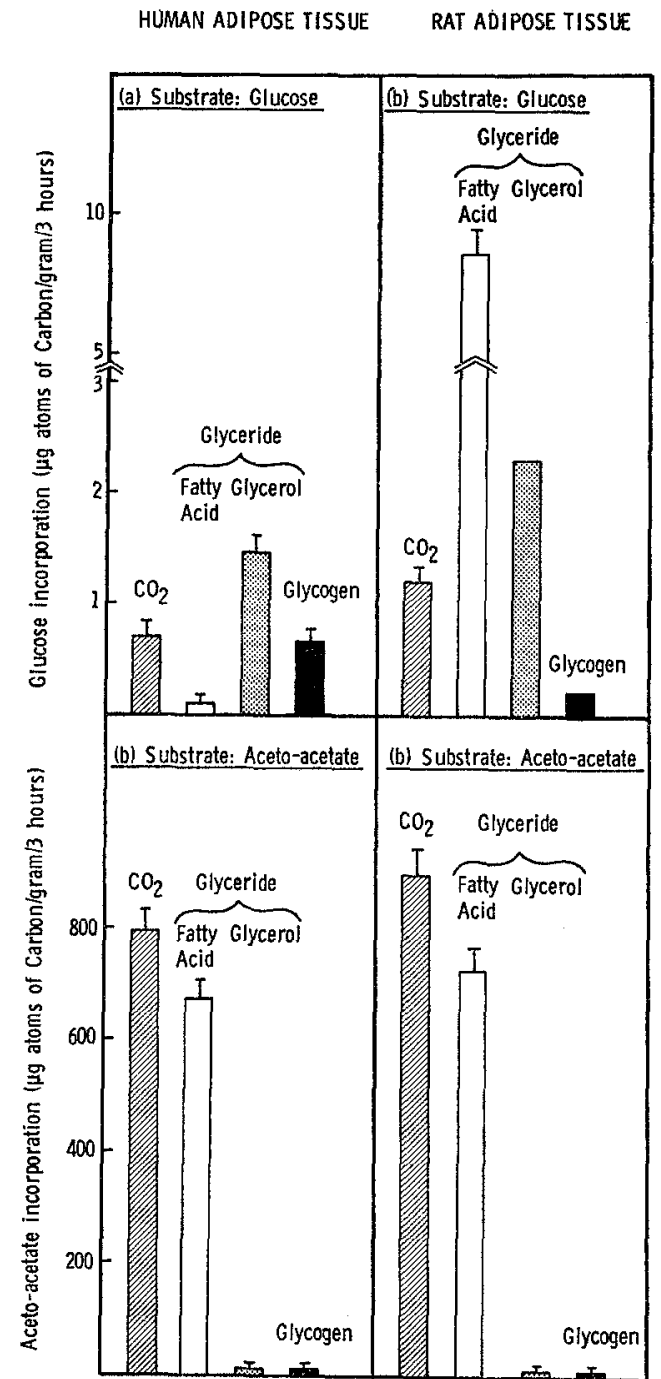

Fig. 1. Metabolic fate of glucose and acetoacetate metabolism in human and rat adipose tissue: Tissue pieces $(100-150 \mathrm{mg})$ were incubated at $37^{\circ} \mathrm{C}$ in $1 \mathrm{ml}$ of buffer containing either acetoacetate $(5 \mathrm{mM})$ or glucose $(5 \mathrm{mM})$ for $3 \mathrm{~h}$. The results are means \pm SEM of 3 separate experiments done in triplicate

lipids was further increased (Fig. 2b). These effects suggested that glucose may affect the pathways of acetoacetate metabolism in human adipose tissue, and the results are summarised in Table 1 . Glucose increased the fatty acid production from acetoacetate by almost 20 -fold. On the other hand, glucose did not affect the oxidation of acetoacetate into $\mathrm{CO}_{2}$. Negligible amounts of radioactivity were recovered in the glyceride glycerol or glycogen fractions during incubation of human adipose tissue with ${ }^{14} \mathrm{C}$ acetoacetate.

The stimulating effect of glucose on fatty acid synthesis from acetoacetate is not due to membrane glucose transport or an osmotic effect, since 2-deoxy glucose at equimolar concentration did not affect fatty acid synthesis from ${ }^{14} \mathrm{C}$ acetoacetate (Table 1 ). 
c) The Effect of Acetoacetate on ${ }^{14} C$ Glucose Metabolism

The effect of acetoacetate on uniformly labelled glucose ${ }^{14} \mathrm{C}$ conversion into total lipids by human adipose tissue fragments is summarised in Fig. 3. At a concentration of $20 \mathrm{mM}$, acetoacetate enhanced incorporation of glucose into lipid. This effect was linear d) The Effect of Free Fatty Acids (FFA) and Very Low Density Lipoproteins (VLDL) on Glucose and Acetoacetate Metabolism by Human Adipose Tissue

Fig. $4 \mathrm{~b}$ shows the effect of increasing concentrations of free fatty acid on glyceride synthesis from glucose. A concentration of $4 \mathrm{mEq} /$ litre of added fatty acids
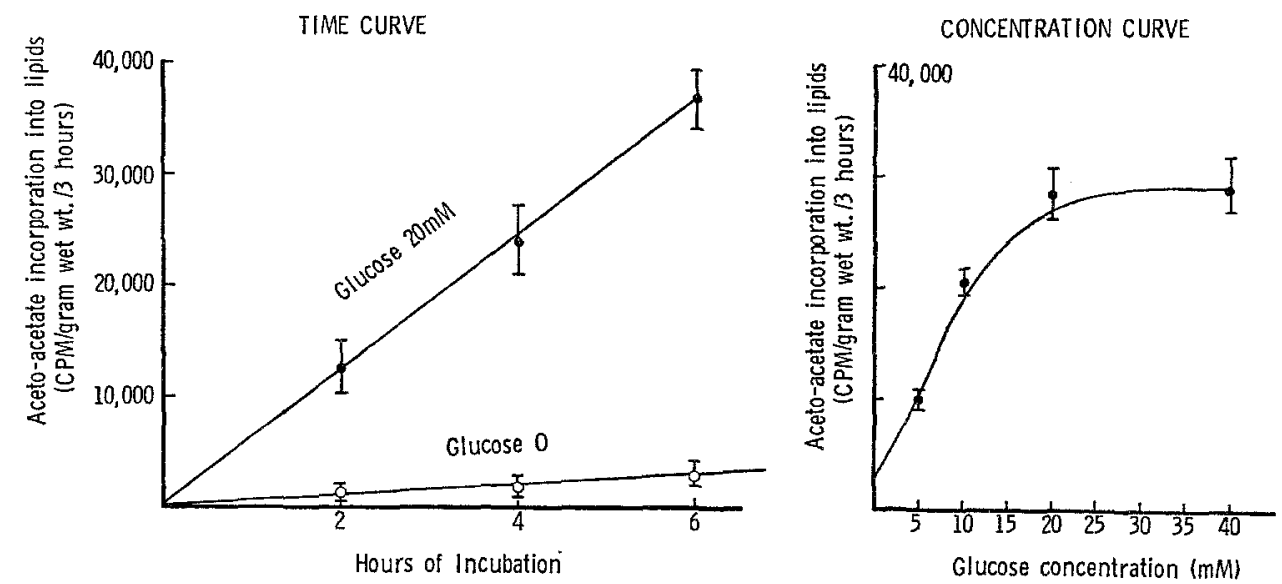

Fig. 2. The effects of glucose on the incorporation of the acetoacetate into lipids by human adipose tissue: A. Time curve with and without glucose $(20 \mathrm{mM})$. B. Concentration curve. Results are means \pm SEM of 3 separate experiments, done in triplicate, scale units for graph B identical to $\mathrm{A}$

Table 1. The incorporation of carbon from ${ }^{14} \mathrm{C}$-3-aceto acetate into $\mathrm{CO}_{2}$, glyceride, fatty acids, glyceride glycerol and glycogen by human adipose tissue in vitro: The effects of glucose and deoxy glucose added to the medium

\begin{tabular}{|c|c|c|c|c|c|c|}
\hline \multirow{2}{*}{$\begin{array}{l}\text { Addition to the } \\
\text { medium } \\
(\mathrm{mM})\end{array}$} & & \multirow{2}{*}{$\begin{array}{l}\text { Aceto acetate } \\
\text { Uptake } \\
(\mu \text { moles } / \mathrm{g} / 3 \mathrm{~h}\end{array}$} & \multicolumn{4}{|c|}{ Aceto acetate incorporated into } \\
\hline & & & $\begin{array}{l}\overline{\mathrm{CO}_{2}} \\
\mu \mathrm{g} \text { atoms }\end{array}$ & $\begin{array}{l}\text { Glyceride fatty } \\
\text { acids } \\
/ \mathrm{g} / 3 \mathrm{~h} \times 10^{3}\end{array}$ & $\begin{array}{l}\text { Glyceride }^{\mathrm{a}} \\
\text { Glycerol }\end{array}$ & Glycogen $^{a}$ \\
\hline None & & $0.25 \pm 0.015$ & $789 \pm 21$ & $69.4 \pm 9$ & $2.4 \pm 0.52$ & $\begin{array}{l}0.06 \pm 0.03 \\
0.045+0.022\end{array}$ \\
\hline $\begin{array}{l}\text { Glucose } \\
\mathrm{P} \quad 5 \\
\mathrm{P} 20\end{array}$ & 20 & $\begin{array}{l}0.50 \pm 0.020 \\
0.52 \pm 0.045 \\
<0.001 \\
<0.001\end{array}$ & $\begin{array}{l}839 \pm 76 \\
\text { NS } \\
\text { NS }\end{array}$ & $\begin{array}{l}1081+44 \\
<0.001 \\
<0.001\end{array}$ & $\begin{array}{c}1.2 \pm 0.60 \\
1.6 \pm 0.22 \\
- \\
-\end{array}$ & $\begin{array}{c}0.045 \pm 0.022 \\
0.086 \pm 0.010 \\
-\end{array}$ \\
\hline & 5 & $0.23 \pm 0.010$ & $816 \pm 44$ & $56.6 \pm 6$ & $2.1 \pm 0.16$ & $0.027 \pm 0.06$ \\
\hline $\begin{array}{l}\text { Deoxy Glucose } \\
\mathrm{P} \quad 5 \\
\mathrm{P} 20\end{array}$ & 20 & $\begin{array}{l}0.26 \pm 0.012 \\
\mathrm{NS} \\
\mathrm{NS}\end{array}$ & $\begin{array}{l}733 \pm 28 \\
\text { NS } \\
\text { NS }\end{array}$ & $\begin{array}{l}\quad 40 \pm 4.6 \\
\text { NS } \\
\text { NS }\end{array}$ & $\begin{array}{c}1.8 \pm 0.26 \\
\text { - }\end{array}$ & $\begin{array}{c}0.042 \pm 0.015 \\
-\end{array}$ \\
\hline
\end{tabular}

Results are means \pm S.D. calculated from 6 experiments, each in triplicate. Incubation volume was $1 \mathrm{ml}$, containing $5 \mathrm{mM}$ of aceto acetate $1 \mu \mathrm{Ci} / \mathrm{ml} .{ }^{3.14} \mathrm{C}$ aceto acetate, incubation conditions are as methods. P 5 and $\mathbf{P} 20$ compares the values in the presence of glucose or deoxyglucose to the appropriate basal values. Levels of significance were calculated by student's $t$-test.

a For determination of glyceride glycerol and glycogen adipose tissue from triplicate incubation was pooled and hence no statistical analysis was performed.

up to $6 \mathrm{~h}$ (Fig. 3a). Further increase in the medium concentration of acetoacetate showed that $20 \mathrm{mM}$ was the optimal concentration for glyceride synthesis from glucose (Fig. 3 b). Table 2 summarises the effects of acetoacetate on the incorporation of glucose in human adipose tissue. Acetoacetate enhanced the glucose incorporation into glyceride glycerol and $\mathrm{CO}_{2}$ without detectable change on its entry into other pathways. maximally stimulated the incorporation of glucose into lipids. Analysis of the lipid fractions showed that over $95 \%$ of glucose radioactivity was incorporated into glyceride glycerol. On the other hand, free fatty acid addition markedly inhibited the synthesis of fatty acids from acetoacetate. Similar effects were observed when triglyceride concentrations of the medium were elevated using purified human VLDL (Fig. 4a). 
e) The Effect of Insulin and Oral Hypoglycaemic Drugs on Glucose and Acetoacetate Metabolism in Adipose Tissue

Insulin $(1 \mathrm{mU} / \mathrm{ml})$ stimulated glucose uptake by human adipose tissue fragments with an increase in both glycogen and glyceride glycerol labelling from ${ }^{14} \mathrm{C}$
U glucose. Insulin did not, however, affect the rate of fatty acid synthesis from glucose (Table 3). In the presence of glucose, insulin stimulated fatty acid synthesis from acetoacetate. Omission of glucose from the medium, however, abolished the stimulating effect of insulin on acetoacetate metabolism (Fig. 5).
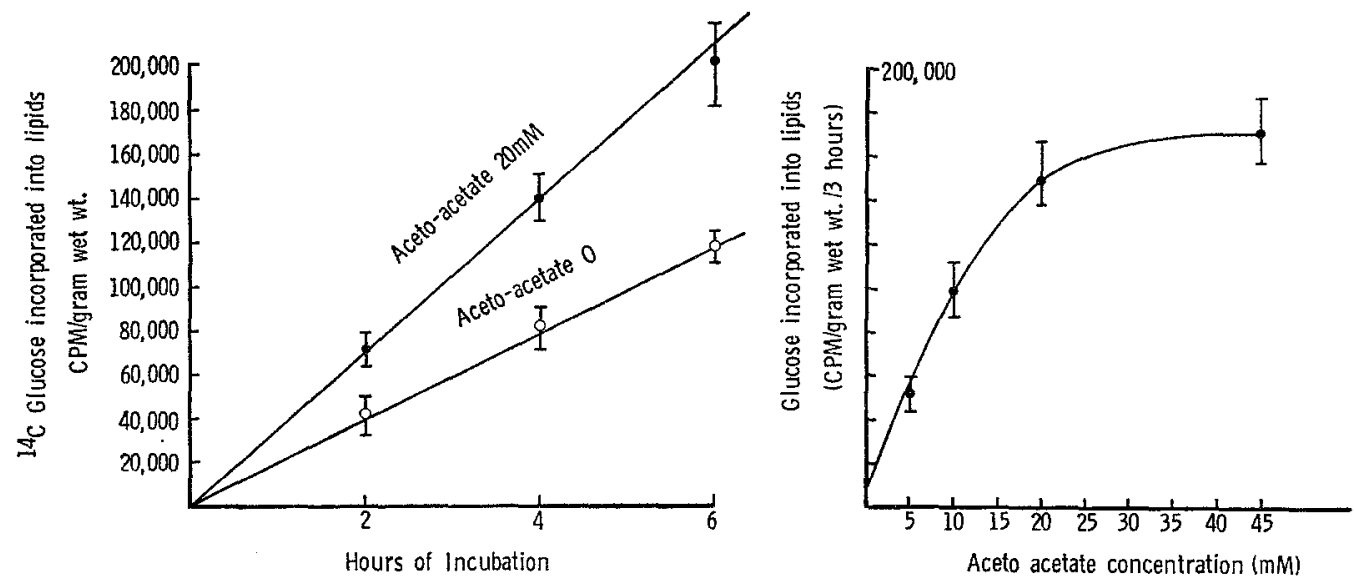

Fig. 3. The stimulating effect of acetoacetate on glyceride synthesis from glucose: A. Time course with and without acetoacetate $(20 \mathrm{mM})$. B. The effect of increasing acetoacetate concentration. The results are means $\pm \mathrm{SEM}$ of 3 separate experiments done in triplicate. Scale units for graph B identical to A

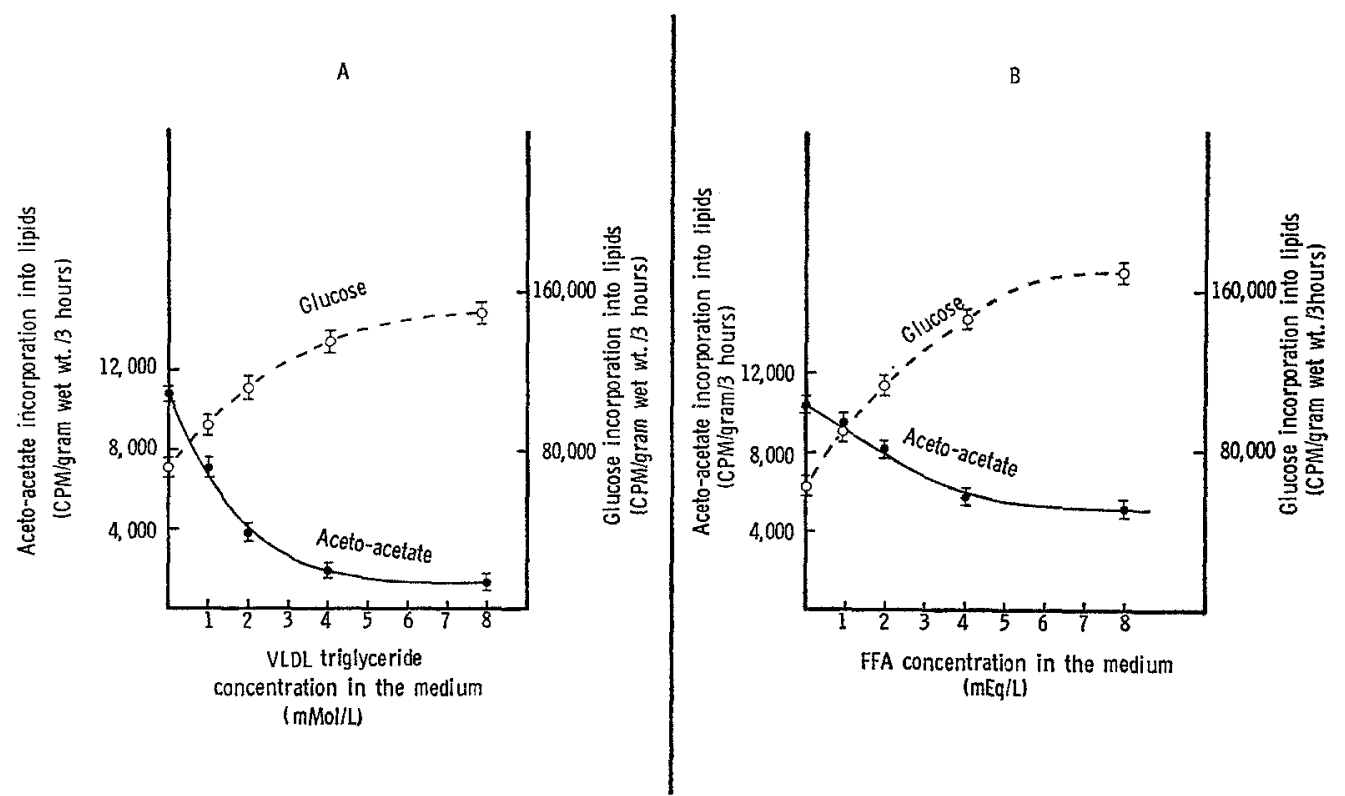

Fig. 4. The effect of VLDL or FFA on glucose and acetoacetate incorporation into lipids by human adipose tissue: A. Human adipose tissue pieces were incubated in medium containing increasing concentrations of VLDL triglyceride

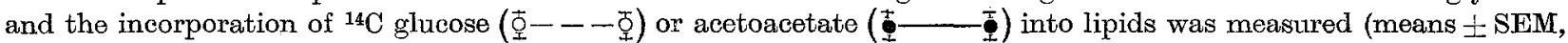
$\dot{n}=3)$. B. The synthesis of lipids from glucose or acetoacetate was measured in the presence of increasing concentrations of free fatty acids. Symbols as in A. Means \pm SEM, $n=3$ 


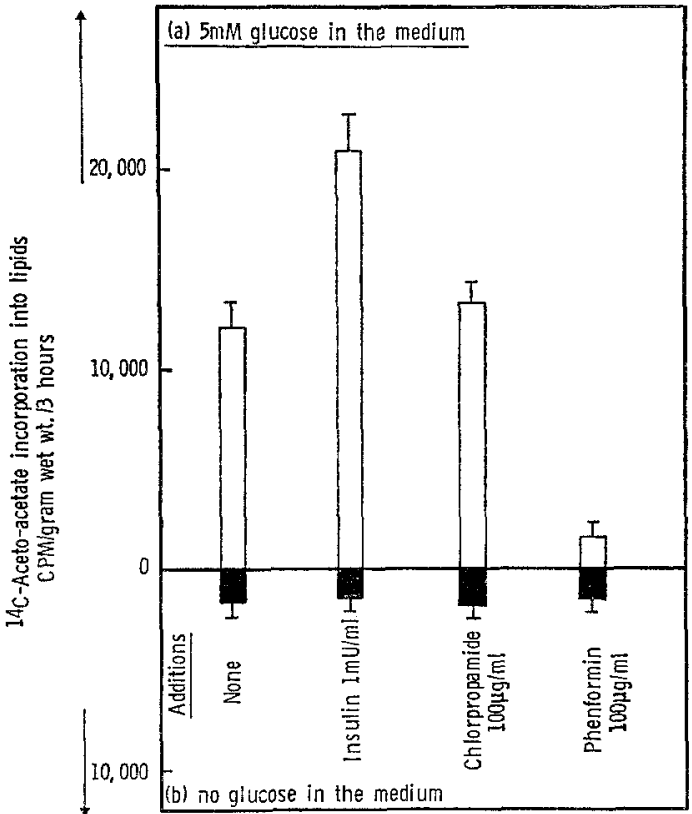

Fig. 5. The effects of insulin and oral hypoglycaemic drugs on the acetoacetate metabolism by human adipose tissue: The incorporation of acetoacetate ${ }^{14} \mathrm{C}$ into adipose tissue lipids was measured (a) in the presence of glucose $5 \mathrm{mM}$ and (b) in the absence of glucose. The results are means \pm SEM, of 2 experiments done in triplicate
The sulphonylurea, chlorpropamide, at a concentration of $100 \mu \mathrm{g} / \mathrm{ml}$ did not influence either glucose or acetoacetate metabolism in human adipose tissue. The lack of effect of chlorpropamide on incorporation rates of glucose and acetoacetate into various intermediates is shown in Table 3 and Fig. 5 . The biguanide Phenformin stimulated $\mathrm{U}_{-14}{ }^{14} \mathrm{C}$ glucose uptake from the medium, but inhibited its incorporation into lipids and glycogen, (Table 3). Phenformin addition also abolished the stimulating effect of glucose on fatty acid synthesis from acetoacetate (Fig. 5).

\section{Discussion}

Ketone bodies are manufactured primarily in the liver and transported through blood to peripheral tissues where they are readily oxidised $[1,2]$. The regulation of hepatic ketone body production has been extensively studied both in vivo and in vitro $[12,13$, 14]. However, little is known about the factors controlling the peripheral utilisation of ketone bodies and its relation to carbohydrate metabolism. Early work suggested that ketone body utilisation was not influenced by carbohydrates and was regulated purely by the supply of ketone bodies to the tissue $[1,15]$. Recent worls using kinetic methods, however, suggests that ketone body incorporation can be influenced by the pattern of glucose metabolism in diabetic rats [16] and dogs [17].

Table 2. The effects of aceto acetate on the incorporation of carbon from $\mathrm{U}^{14} \mathrm{C}$ glucose into $\mathrm{CO}_{2}$, glyceride glycerol, glyceride fatty acids and glycogen of human adipose tissue incubated in vitro

\begin{tabular}{|c|c|c|c|c|c|}
\hline \multirow[t]{2}{*}{ Addition to the medium } & \multirow{2}{*}{$\begin{array}{l}\text { Glucose } \\
\text { Uptake }\end{array}$} & \multicolumn{4}{|c|}{ Glucose incorporated into } \\
\hline & & & $\begin{array}{l}\text { Glyceride fatty } \\
\text { acids }\end{array}$ & $\begin{array}{l}\text { Glyceride } \\
\text { glycerol }\end{array}$ & Glycogen \\
\hline$(\mathrm{mM})$ & $\mathrm{m}$ moles $/ \mathrm{g} / 3 \mathrm{~h}$ & \multicolumn{4}{|c|}{$\mu \mathrm{g}$ atoms carbon $/ \mathrm{g} / 3 \mathrm{~h} \times 10^{8}$} \\
\hline None & $0.82 \pm 0.12$ & $690 \pm 105$ & $102 \div 28$ & $1140 \pm 310$ & $648 \pm 210$ \\
\hline Aceto acetate (5) & $1.4 \pm 0.09$ & $919 \pm 79$ & $89 \pm 34$ & $4626 \pm 148$ & $694 \pm 162$ \\
\hline Aceto acetate (20) & $1.89 \pm 0.16$ & $1579 \pm 110$ & $116 \pm 16$ & $6246 \pm 109$ & $810 \pm 114$ \\
\hline $\mathbf{P} 5$ & $<0.001$ & $<0.01$ & NS & $<0.001$ & NS \\
\hline P 20 & $<0.001$ & $<0.001$ & NS & $<0.001$ & NS \\
\hline
\end{tabular}

Values are means of 6 experiments done in triplicate \pm S.D. Glucose was present in the medium at a concentration of $5 \mathrm{mM}, 1 \mu \mathrm{Ci} \mathrm{U-14} \mathrm{C}$-glucose in a total volume of $1 \mathrm{ml}$. Incubation methods are as described in the methods. P5 and $\mathbf{P} 20$ compares the values attained in the presence of acetoacetate compared to basal conditions, using student's $t$-test.

Table 3. Effects of insulin and oral hypoglycaemic agents on the incorporation of $U_{-}{ }^{14} \mathrm{C}-g l u c o s e ~ i n t o ~ C \mathrm{O}_{2}$, glyceride fatty acids, glyceride glycerol and glycogen in human adipose tissue

\begin{tabular}{|c|c|c|c|c|}
\hline \multirow[t]{3}{*}{ Addition to the medium } & \multirow{3}{*}{$\begin{array}{l}\text { Glucose } \\
\text { Uptake } \\
\text { m Moles/g/3 h }\end{array}$} & \multicolumn{3}{|c|}{ Glucose incorporated into: } \\
\hline & & $\begin{array}{l}\text { Glyceride fatty } \\
\text { acids }\end{array}$ & Glyceride glycerol & Glycogen \\
\hline & & \multicolumn{3}{|c|}{$\mu \mathrm{g}$ atoms carbon $/ \mathrm{g} / 3 \mathrm{~h} \times 10^{3}$} \\
\hline (Basal) & $0.85 \pm 0.18$ & $86 \pm 28$ & $1042 \pm 111$ & $576 \pm 65$ \\
\hline Insulin $(1 \mathrm{mU} / \mathrm{ml})$ & $1.62 \pm 0.12$ & $106 \pm 36$ & $3306 \pm 115$ & $2050 \pm 124$ \\
\hline $\mathbf{P}$ & $<0.001$ & NS & $<0.001$ & $<0.001$ \\
\hline Chlorpropamide & $0.78 \pm 0.09$ & $98 \pm 19$ & $984 \pm 78$ & $614 \pm 46$ \\
\hline $\mathrm{P}$ & NS & NS & NS & NS \\
\hline $\begin{array}{l}\text { Phenformin }(100 \mu \mathrm{g} / \mathrm{ml}) \\
\mathbf{P}\end{array}$ & $\begin{array}{l}1.46 \pm 0.14 \\
<0.01\end{array}$ & $\begin{array}{l}30 \pm 6 \\
<0.005\end{array}$ & $\begin{array}{c}103 \pm 26 \\
<0.001\end{array}$ & $\begin{array}{l}102 \pm 13 \\
<0.001\end{array}$ \\
\hline
\end{tabular}

Values are means \pm S.D. from 6 separate experiments, each performed in triplicate. Glucose was present in the medium at a concentration of $5 \mathrm{~m}$ Molar $\left(1 \mu c i \mathrm{U}-{ }^{14} \mathrm{C}\right.$-glucose). Incubation conditions as described in methods. $P$ values denote probabilities between the presence of insulin or oral hypoglycaemics compared with control tubes using student's $t$-test. 
Our results show that human adipose tissue utilises acetoacetate in vitro. The conversion of acetoacetate into fatty acids and $\mathrm{CO}_{2}$ requires its initial activation into acetoacetyl S-CoA. Two acetoacetate thiokinases have been recently identified in brown adipose tissue [18]. Furthermore, the succinyl thiophorase system described by Stein et al. [19] in skeletal muscle could also convert acetoacetate into acetoacetyl S-COA. If this pathway is present in human adipose tissue, acetoacetyl S-CoA could be a common precursor for both fatty acid synthesis and $\mathrm{CO}_{2}$ production.

The increased fatty acid synthesis from ${ }^{14} \mathrm{C}$ acetoacetate in the presence of glucose has been demonstrated previously in rat adipose tissue [6, 7]. Glucose enhances the formation of triglycerides and thus minimises the accumulation of intracellular long chain fatty acyl-S-CoA which is known to inhibit further fatty acid synthesis [23, 24]. Moreover, glucose favours lipogenesis by generation of NADPH which is essential for fatty acid synthesis. The enhancement of fatty acid synthesis from acetoacetate was not associated with a comparable increase in $\mathrm{CO}_{2}$ production. This observation might suggest that acetoacetate is activated to aceto-acetyl-S-CoA and incorporated into fatty acids without being first broken down to acetyl S-CoA.

The stimulant effect of acetoacetate on glucose metabolism in human adipose tissue is in marked contrast to its reported effects in muscle $[1,2,3]$. The fact that these two tissues react differently to ketone bodies is not surprising since the metabolism of glucose in these tissues is also markedly different. In contrast to the rat, human adipose tissue metabolises glucose mainly to glyceride glycerol. A minor fraction of the glucose utilised is converted to fatty acid. The basis for this particular metabolism by human adipose tissue has yet to be defined. Shrago et al. $[20,21]$ demonstrated a decrease in the enzymes generating acetyl $\mathrm{S}$-CoA from glucose in human adipose tissue. Others believe that high activity of alpha glycerophosphate dehydrogenase in this tissue favours alpha glycerophosphate synthesis from glucose $[25,26]$. We favour the second possibility, since human adipocytes could effectively incorporate pyruvate and acetate into fatty acids in the presence of glucose in the medium [33]. It seems reasonable therefore to believe that ketone bodies stimulate glucose utilisation since the fatty acid synthesised from acetoacetate would stimulate the further synthesis of alpha glycerophosphate from glucose [27]. The increase in $\mathrm{CO}_{2}$ production from ${ }^{14} \mathrm{C}$ labelled glucose in the presence of acetoacetate could be attributed to the generation of succinate from the succinate thiophorase system during acetoacetate activation.

The diabetic state is characterised by a number of metabolic derangements among which are elevations in plasma FFA and triglycerides $[28,29,30,31]$. In order to evaluate the role of these two compounds in the development of ketosis we measured the incorporation of glucose and acetoacetate into lipids in their presence. Free fatty acids and triglyceride fatty acids are astively utilised by human adipocytes [32]. In vitro addition of these substrates enhanced the incorporation of glucose into triglycerides. However, fatty acid synthesis from acetoacetate was markedly inhibited by the addition of either substrate. The effect of fatty acid and VLDL on glucose metabolism might have been expected since these compounds will ultimately raise intracellular levels of fatty acyl-CoA, resulting in stimulation of glucose conversion to glyceride glycerol [27]. The accumulation of intracellular fatty acyl-CoA on the other hand, would inhibit fatty acid synthesis from acetoacetate [23].

The effects of glucose on acetoacetate metabolism could not be linked to glucose transport since 2-deoxyglucose at equivalent concentration did not affect acetoacetate utilisation. It seems, therefore, that it is the pattern of glucose metabolism, rather than its transport, which determines the fate of acetoacetate. Insulin stimulates glucose utilisation and its incorporation into glyceride glycerol. This would prevent the accumulation of intracellular fatty acyl-CoA through esterification and therefore favour continued fatty acid synthesis from acetoacetate. In contrast, phenformin inhibits the synthesis of glyceride glycerol from glucose, despite stimulating glucose uptake from the medium. Fatty acid synthesis was also inhibited.

These experiments did not identify the causative factor underlying insulin resistance during diabetic ketosis. They do, however, exclude the possibility that ketone bodies interfere with glucose utilisation in normal human adipose tissue. The physiological mechanisms governing glucose, fatty acid and ketone body utilisation in diabetic human adipose tissue remain, however, to be evaluated.

Aclenowledgements. We wish to thank the Medical Research Council for their continued support, and the Wellcome Trust for a Senior Clinical Research Fellowship to one of us (BRT). We are indebted to our surgical colleagues for the supply of normal human subcutaneous adipose tissue.

\section{References}

1. Williamson, J.R., Krebs, H.A.: Acetoacetate as fuel of respiration in the perfused rat heart. Biochem. J.80, $540-547$ (1961)

2. Neptune, E.M., Jr., Sudduth, H.C., Fash, F.J., Reish, J.J.: Metabolism of beta hydroxybutyrate and acetoacetate by excised rat diaphragm and diaphragm homogenate. Amer. J. Physiol. 201, 235-238 (1961)

3. Randle, P.J., Garland, P.B., Hales, C.N., Newsholme, E.A.: Glucose fatty acid cycle. Lancet 1963 I, 785789

4. Randle, P.J., Garland, P.B., Hales, C.N., Newsholme, E.A., Denton, R.M., Pogston, C.F.: Interaction, metaboliam and physiological role of insulin. Recent Prog. Horm. Res. 22, 1-48 (1966) 
5. Krebs, H. A., Eggleston, L.V., D'Alessandro, A.: The effect of succinate and amytal on the reduction of acetoacetate in animal tissues. Biochem. J. 79, 537549 (1961)

6. Hanson, R.W., Ziporin, Z.Z.: Factors influencing the utilisation of ketone bodies by mouse adipose tissue. J. Lipid Res. 7, 56-60 (1966)

7. Söling, H.D., Zahlten, R., Reimold, W.V., Willms, B.: Utilisation of ketone bodies by adipose tissue and its regulation by carbohydrate metabolism. Horm. Metab. Res. 2, 56-61 (1970)

8. Folch, J., Lees, M., Sloan Stanley, G.H.: A simple method for the isolation and purification of total lipides from animal tissues. J. biol. Chem. 226, 497509 (1957)

9. Denton, R.M., Randle, P.J.: Measurement of flow from carbon atoms from glucose and glycogen glucose to glyceride glycerol and glycerol in rat heart and epididymal adipose tissue. Biochem. J. 104, 423-434 (1967)

10. Stetten, M.R., Katzen, H.M., Stetten, D.: A comparison of the glycogens isolated by acid and alkaline procedures. J. biol. Chem. 475, 481-487 (1958)

11. Cramp, D.G.: New automated method for measuring glucose by glucose oxidase. J. clin. Path. 20, 910-912 (1967)

12. Campbell, J., Best, C.H.: Physiologic aspects of ketosis. Metabolism 5, 95-113 (1956)

13. Krebs, H.A.: The regulation of the release of ketone bodies by the liver. Advanc. Enzym Regulat. 4, 339353 (1966)

14. Wieland, O.: Ketogenesis and its regulation. Advanc. Metab. Disord. 3, 1-48 (1968)

15. Blixenkrone, A., Möller, N.: Über den Abbau von Ketonkörpern Hoppe-Seylers. Z. Physiol. Chem. 253, $261-266(1938)$

16. Bassler, K.H., Horbach, L., Wagner, K.: Dynamies of ketone body metabolism in diabetic rats. Diabetologia 8, 211-214 (1972)

17. Balasse, E. O., Havel, R.J.: Evidence for an effect of insulin on the peripheral utilization of ketone bodies in dogs. J. clin. Invest. 50, 801-813 (1971)

18. Rossi, C.R., Drahota, Z., Alexandre, A., Siliprandi, M.: On the presence of two acetoacetate thiokinases, GTP-and ATP-specific in brown adipose tissue mitochondria. Abstr. No. 215, VII. Meeting Fed. Europ. Biochem. Soc. 1969

19. Stern, J.R., Coon, M. J., Del Campillo, A.: Breakdown and synthesis of alpha ketoacids. J. biol. Chem. 221, $1-14(1956)$
20. Shrago, E., Glennion, J.A., Gordon, E.S.: Enzyme studies in human liver and adipose tissue. Nature (Lond.) 212, 1263 (1966)

21. Shrago, E., Spennetta, T., Gordon, E.S.: Fatty acid synthesis in human adipose tissue. J. biol. Chem. 244, $2761-2766(1969)$

22. Hall, L.M.: Preparation of crystalline lithium acetoacetate. Anal. Biochem. 3, 75-80 (1962)

23. Bortz, W., Lynen, F.: The inhibition of acetyl CoA carboxylase by long-chain acyl CoA derivatives. Biochem. Z. 337, 505-509 (1963)

24. Tubbs, P.K., Garland, P.B.: Fatty acyl thio esters of coenzyme A: Inhibition of fatty acid synthesis in vitro and determination of levels in liver in normal fasted and fat - or sugar - fed rats. Biochem. J. 89, $25-31(1963)$

25. Shonk, C.E., Boxer, G.E.: Enzyme patterns in human adipose tissue: Determination of glycolytic enzymes. Cancer Res. 24, 709-721 (1964)

26. Galton, D.J., Bray, G.A.: Metabolism of glycerol-3 phosphate in human adipose tissue in obesity. J. clin. Endocr. 27, 1573-1586 (1967)

27. Saggerson, E.D.: The regulation of glyceride synthesis in isolated white fat cells, the effects of palmitate and lipolytic agents. Biochem. J. 128, 1057-1067 (1972)

28. Bierman, E.L., Dole, V.P., Roberts, M.T.: An abnormality of NEFA in diabetes mellitus. Diabetes 6, $475-479(1957)$

29. Bagdade, J., Porte, D., Bierman, E.L. : Acute insulin withdrawal and the regulation of plasma triglycerides in diabetics. Diabetes 17, 127-132 (1968)

30. Elkeles, R., Lowy, C., Wyllie, A., Young, J. I., Fraser, T.R.: Serum insulin, glucose and lipid levels among mild diabetics in relation to the incidence of vascular complications. Lancet 1971 I, $880-882$

31. Lewis, B., Mancini, M., Mattock, M., Chait, A., Fraser, T.R.: Plasma triglyceride and FFA metabolism in diabetes mellitus. Europ. J. clin. Invest. 2, 445-453 (1972)

32. Wilson, J., Guttman, R., Galton, D.J.: Glyceridefatty acid and FFA uptake by human adipose tissue in obesity. Clin. Sci. (In Press)

33. Kissebah, A.H., Tulloch, B.R.: Unpublished results

Dr. A.H. Kissebah

Endocrine Unit

Dept. of Medicine

Royal Postgraduate Medical School

Hammersmith Hospital

Ducane Road

London W 12 OHS

England 